Jurnal Ekonomi Syariah Teori dan Terapan p-ISSN: 2407-1935, e-ISSN: 2502-1508. Vol. 8 No. 3 Mei 2021: 255-263; DOI: 10.20473/vol8iss20213pp255-263

\title{
EFFECT OF MUDARABAH AND MUSHARAKAH FINANCING ON RETURN ON EQUITY (ROE) CASE STUDIES ON ISLAMIC COMMERCIAL BANKS IN INDONESIA FOR THE PERIOD 2015-2019
}

\section{PENGARUH PEMBIAYAAN MUDHARABAH DAN MUSYARAKAH TERHADAP RETURN ON EQUITY (ROE) STUDI KASUS BANK UMUM SYARIAH DI INDONESIA PERIODE 2015- 2019}

\author{
Ghitha Millatina Islamiyati, Nana Diana \\ Accounting Study Program - Faculty of Economics and Business - Universitas Singaperbangsa Karawang \\ 1710631030080@ student.unsika.ac.id*,nana.diana@fe.unsika.ac.id
}

\begin{abstract}
ABSTRAK
Tujuan dari penelitian ini adalah untuk mengetahui apakah pembiayaan mudharabah dan pembiayaan musyarakah berpengaruh terhadap Return On Equity (ROE) studi kasus pada Bank Umum Syariah di Indonesia periode 2015 2019. Populasi dalam penelitian ini adalah seluruh data dalam laporan keuangan yang terdapat pada Bank Umum Syariah di Indonesia dan didapat sampel dari hasil purposive sampling sebanyak 9 Bank Umum Syariah dengan variable bebas yaitu pembiayaan mudharabah $(X 1)$ dan pembiayaan musyarakah (X2) serta variabel tetap yaitu Return On Equity (ROE) (Y). Metode penelitian yang digunakan yaitu analisis deskriptif, uji asumsi klasik yang terdiri dari uji normalitas, uji heteroksiditas, uji multikolinearitas dan uji autokorelasi juga uji hipotesis yang terdiri dari uji statistic t untuk menguji secara terpisah, uji statistic F untuk menguji secara bersama dan koefisien determinasi (R2). Hasil penelitian menjelaskan bahwa secara terpisah, Return On Equity (ROE) tidak dipengaruhi oleh pembiayaan mudharabah maupun pembiayaan musyarakah.. Pada uji secara bersama-sama, Return On Equity (ROE) tidak dipengaruhi oleh pembiayaan mudharabah dan pembiayaan musyarakah studi kasus Bank Umum Syariah di Indonesia periode 2015-2019.
\end{abstract}

Kata Kunci: pembiayaan mudharabah, pembiayaan musyarakah, return on equity ROE), bank umum syariah.

\footnotetext{
ABSTRACT

The intention of this research is to reveal whether mudarabah and musharakah financing have an effect on the return on equity (ROE) case studies on Islamic Commercial Banks in Indonesia period 2015-2019. The population in this research is all data in the financial reports contained in Islamic Commercial Banks in Indonesia and obtained samples from the purposive sampling of 9 Islamic Commercial Banks with independent variables, namely mudarabah financing (X1) and musharakah financing (X2) and dependent variable namely return on equity (ROE) (Y). The research method used are analysis of descriptive, test of classic assumption which contains test of normality, heteroxidity test, multicollinearity test and autocorrelation test as well as hypothesis testing which includes $t$ statistical test to test partially, statistical F test to test simultaneously and the coefficient of determination $(R 2)$. The results of the research explain that partially, return on equity ( $R O E$ ) has no effected by mudarabah financing and musharakah financing. In the simultaneous test, return on equity (ROE) has no effected by mudarabah financing and musharakah financing in case study of Islamic Commercial Banks in Indonesia for the 2015-2019 period.

Keywords: Mudarabah financing, musharakah financing, return on equity (ROE), Islamic commercial bank.
}

Informasi artikel

Diterima: 02-02-2021

Direview: 03-05-2021

Diterbitkan: 30-05-2021

${ }^{*}$ Korespondensi (Correspondence): Ghitha Millatina Islamiyati

Open access under Creative Commons Attribution-Non Commercial-Share A like 4.0 International Licence (CC-BY-NC-SA) (C) (1) 
Islamiyati, et al/Jurnal Ekonomi Syariah Teori dan Terapan Vol. 8 No. 3 Mei 2021: 255-263

\section{INTRODUCTION}

The increase in the use of the Islamic banking system in conventional banking has increased significantly in the last few years. This relates to the issuance of Law No.10 of 1998 concerning amendments to Law No.7 of 1992 concerning Banking and the issuance of the Haram Bank Interest Fatwa from the Indonesian Ulama Council (MUI) in 2003 to encourage conventional banking to establish Islamic banking also apply sharia principles. This is supported by some Indonesian people who are Muslim because it is in accordance with Islamic principles which does not contain elements of usury, applies the principle of openness and profit sharing so that it is felt capable of providing justice for customers and stability for the banking itself.

When a company, especially an Islamic bank, get profits from sales, total assets, and its own equity, indicators are needed to assess how much profit is achieved, one of which is the ratio of return on equity (ROE). The ROE ratio uses its own capital as a determinant of how much profit a bank makes. The better a bank is in managing its capital, the better the performance of the bank is. With this ROE ratio indicator, it can be used as a consideration for investors in investing their capital and also can be used as a basis for lending for creditors.

The calculation of return on equity (ROE) is influenced by sharia banking products in the form of services which in fact apply profit sharing, namely mudarabah financing and musharakah financing, where both financing is a joint agreement between the bank and the customer with profit sharing conditions. The value of Mudarabah and Musharakah financing will affect the result of return and will affect the profitability obtained. This is because when the financing flows smoothly, the bank will get a profit where the profit is used to return the equity used, whereas if the financing gridlock or experiences a loss it will result in decreased profits.

The following is mudarabah financing, musharakah financing and ROE in one of the sharia banks, namely PT. Bank Jabar Banten Syariah for the period 2015-2019.

Table 1.

Mudarabah Financing, Musharakah Financing and Return on Equity (ROE)

PT. Bank Jabar Banten Syariah Periode 2015-2019.

(in thousands of rupiah)

\begin{tabular}{|r|r|r|r|}
\hline Year & Mudarabah & Musharakah & \multicolumn{1}{|c|}{ ROE (\%) } \\
\hline 2015 & Rp.317,180,236 & Rp.726,254,242 & $0.92 \%$ \\
\hline 2016 & Rp.204,505,878 & Rp.668,816,485 & $-49.05 \%$ \\
\hline 2017 & Rp.149,532,197 & Rp.638,463,460 & $-58.64 \%$ \\
\hline 2018 & Rp.122,993,787 & Rp. $1,087,188,211$ & $2.63 \%$ \\
\hline 2019 & Rp.169,935,619 & Rp. $1,491,596,624$ & $2.33 \%$ \\
\hline
\end{tabular}

Source: the results of the data were processed.2021

Maharani (2019) states when the value of financing increases, banks will increase the percentage of profitability, especially ROE, so that bank will get business profits. Conversely, if the financing provided was not convenient, it will cause loss to banking business. Can be seen in the data of PT. Bank Jabar Banten Syariah for the period 2015-2019 that in 2015-2017 mudarabah financing decreased sequentially from Rp.317,180,236,000 to Rp.204,505,878,000 and continues to decline to Rp.149,532,197,000. The same thing happened to musharakah financing which had decreased for 3 consecutive years from Rp.726,254,242,000 decreased to Rp.668,816,485,000 and getting down to Rp.638,463,460,000. When mudarabah financing and musharakah financing decreased, the ROE earned had decreased in those 3 years.

This data proves that when mudarabah financing and musharakah financing have decreased, the ROE will also decrease. This data is in line with research done by Mahmudin (2018) and Rianti \& Elmanizar (2019) which concluded that mudarabah and musharakah financing partially or simultaneously have a significant effect on return on equity (ROE). But it is inversely proportional to the research of A. E. Rianti (2019) and Putra \& Hasanah (2016) which state that mudarabah financing and musharakah financing have 
Islamiyati, et al/Jurnal Ekonomi Syariah Teori dan Terapan Vol. 8 No. 3 Mei 2021: 255-263

no effect on return on equity (ROE) which means that increases or decreases in mudarabah financing and musharakah financing has nothing to do with increase or decrease in return on equity (ROE).

\section{Formulation of the Problem}

Based on the background previously described, there are many differences between one study and another. That way the author can formulate problems in research, namely:

1. Does mudarabah financing effect return on equity (ROE) in Islamic Commercial Banks in Indonesia for the 2015-2019 period?

2. Does musharakah financing effect return on equity (ROE) in Islamic commercial banks in Indonesia for the 2015-2019 period?

3. Do mudarabah financing and musharakah financing jointly effect return on equity (ROE) in Islamic Commercial Banks in Indonesia for the 2015-2019 period?

\section{Research intentions}

1. To find out how the effect of mudarabah financing on return on equity (ROE) in Islamic Commercial Banks in Indonesia for the 2015-2019 period.

2. To find out how the influence of musharakah financing on return on equity (ROE) in Islamic Commercial Banks in Indonesia for the 2015-2019 period.

3. To find out how the effect of mudarabah financing and musharakah financing jointly on return on equity (ROE) in Islamic Commercial Banks in Indonesia for the 2015-2019 period.

\section{THEORITICAL BASIS}

Return on Equity (ROE)

Ratio of profitability is used to measure how much company capabilities to earn profits as seen from total assets, own capital and sales. One of the profitability ratios used by the company is the Return on Equity (ROE). According to Financial Services Authority Circular Letter Number 18/SEOJK.03/2015 Return on equity (ROE) is a comparability of earning after tax with average capital or bank equity (Nataliawati, 2018). Return on equity is an indicator to measure management capabilities in manage their own capital for profit.

By optimizing the capital owned, the effectiveness of the company can be seen with the ROE ratio. When the profit generated by the company is high, the resulting ROE value will be high too. This indicates that when a company has good effectiveness in managing its capital, the profits it generates will be good (Nataliawati, 2018). When the ROE ratio has increased, the company's net profit has also increased so that the ROE ratio indicator is usually used as a benchmark for investors in making investment decisions to invest in a company (Maharani, 2019).

The Return on Equity (ROE) ratio can be formulated as follows:

$$
\mathrm{ROE}=\frac{\text { Net Income }}{\text { Equity }} \times 100 \%
$$

\section{Mudarabah Financing}

According to paragraph 4 of PSAK 105, the definition of mudarabah financing refers to a business partnership contract between two parties. First party (the holder of the funds or shahibul maal) appropriate all the funds and second party (fund administrator or mudharib) act as managers and profits are divided accordingly. Agreement and the capital failure are only borne by the capital holder and not caused by the fault of the fund of administrator, the loss will be borne by the fund owner. If the loss is caused by the fault of the fund administrator, the failure will be borne by the fund manager (IAI, 2007; Fatmawati, 2016).

Mudarabah financing is appropriate by Islamic banks on the trust basis. When bank provide funds to customers to run their businesses, Islamic banks give full confidence to these customers. Business managers or mudharib are only given certain suggestions by Islamic banks in carrying out their business in 
Islamiyati, et al/Jurnal Ekonomi Syariah Teori dan Terapan Vol. 8 No. 3 Mei 2021: 255-263

order to obtain optimal business results (Daulay, 2019). According to Rahayu, Husaini, \& Azizah (2016), there are two types of mudarabah financing, namely Mudarabah muqayyadah (cooperation between shahibul maal and mudharib where the place and type of business to be managed by the customer can be determined freely by the mudharib) and Mudarabah mutlaqah (place and the type of business to be managed by the customer cannot be determined by the mudharib).

\section{Musharakah Financing}

According to Rivai (2010:193), Rahayu, Husaini, \& Azizah (2016) musharakah financing is financing conducted by a bank that acts as the funds holder or joins as a business partner organized by another party. The profit obtained is consistent with the amount of investment capital agreed at the beginning of the agreement. If the business fails, the losses will be shared in accordance with the shareholding ratio.

In musharakah financing, the capital provided by Islamic banks is in accordance with the portion that has been agreed with the customer. For example, a customer has a capital of $25 \%$ and requires a remaining capital of $75 \%$, the Islamic bank will provide $75 \%$ of its capital based on the agreed musharaka agreement (Sari \& Anshori, 2016). Musharaka financing has two types of financing, namely Syirkah AlMilk (Musharakah which occurs when two or more people acquire ownership of the same asset which comes from a will or family inheritance) and Syirkah Al-Uqud (Musharakah which occurs when two or more people have a cooperation agreement. to share the same capital and share the same profits and losses in building a business to achieve certain goals) (Nalta, Wijaya, \& Al Amin, 2018).

\section{Research Hypothesis}

Based on the explanation of the theoretical basis that has been put forward, the hypotheses in this study are:

$\mathrm{H} 1$ = mudarabah financing has an effect on return on equity (ROE)

$\mathrm{H} 2$ = musharakah financing has an effect on return on equity (ROE)

$\mathrm{H} 3$ = mudarabah financing and musharakah financing together have an effect on return on equity (ROE)

\section{RESEARCH METHODS}

Data collection in this research uses secondary data from financial reports (annual reports) published on the websites of each Islamic bank and can be seen on the website of the Financial Services Authority (OJK). All data entered into the financial statements of 14 Islamic banks are population in this study with the sample used, namely 9 Islamic commercial banks selected using purposive sampling method with the following criteria: 1) Islamic Commercial Banks in Indonesia for the period 2015- 2019; 2) The bank has financial report in the form of an annual report for the 2015-2019 period and has been published by the Financial Services Authority (OJK); 3) Sharia Commercial Banks conducting Mudarabah and Musharakah contracts during the 2015-2019 period.

When the data has been collected, then a classic assumption test is needed to clarify whether the estimation model used in the research is appropriate so that there is no bias in the model. The classical assumption tests used are 1) test of normality; 2) test of heteroscedasticy; 3) test of multicollinearity; and 4) test of autocorrelation.

In this study, hypothesis testing was also used to reveal the correlation between independent variable and dependent variable. Mudarabah financing (X1) and musharakah financing (X2) are the independent variables and return on equity (ROE) is the dependent variable is used in this research. There are several hypothesis tests used in this study, including:

1. The t statistical test is used to show how far the influence of Mudarabah Financing and Musharakah Financing are independent variables which are independent variables individually in clarifying the variation of return on equity (ROE) which is the dependent variable (Ningrum, Setiono, \& Dwihandoko, 2019); 
Islamiyati, et al/Jurnal Ekonomi Syariah Teori dan Terapan Vol. 8 No. 3 Mei 2021: 255-263

2. The F statistical test is to find out whether Mudarabah Financing and Musharakah Financing, which are independent variables in the regression model, are able to explain the dependent variable, namely return on equity (ROE) (Wibowo \& Sunarto, 2014); and

3. Coefficient determination $\left(\mathrm{R}^{2}\right)$ which is intent to reveal how percentage transform in dependent variable (Y) is controlled by independent variable (X) (Maharani, 2019).

\section{RESULTS AND DSCUSSION}

Descriptive analysis

In this research, analysts obtained on descriptive data, namely, in table 2 it is known that the sample used in this study was 45 which came from a sample of Islamic Commercial Banks for the 2015-2019 period. Variable Y (ROE) in this study obtained an average of 1.64, minimum value of 94.01, maximum value of 15.66 and a standard deviation of 19.47. In mudarabah financing (X1), an average of 934692890357.80 is obtained, a minimum value is 4513711303, a maximum value of 8701140000000 and a standard deviation of 1466452478291.45. In musharakah financing (X2) an average of 6500762150075.55 is obtained, the minimum value is 638463460000 , the maximum value of 8701140000000 and the standard deviation is 1466452478291.45 .

\section{Normality Test}

The test of normality is operated to clarify whether the data used in this study are distributed normally or not. From the data table 3, it is obtained that data used in this research is distributed normally. Got result of the value of significance is $1.1758 \mathrm{E}-8$ where this value is huger than 0.05 so that the data is normal.

\section{Heteroxidity Test}

If a residual regression model from one observation to another there is a different variance, then the model experiences heteroxicity and if there is the same variance it is said to be homoscedasticity. A good model will not experience heteroxidity. It can be seen how the distribution of points is scattered between 0 values or forms a certain pattern on the scatterplot chart.

It can be known from Figure 1 that the points scatter evenly among 0 values on the $\mathrm{Y}$ axis so that the model is considered good because it is a homoscedasticity model and not a heteroxidity model.

\section{Multicollinearity Test}

Multicollinearity occurs when the VIF value obtained from the calculation results is more than 10 and the tolerance value is more than 0.10 . A good regression model will not have multicollinearity because the model will be good if independent variables have no correlation each other.

Judging from the results of table 4, the VIF value obtained in mudarabah financing and musharakah financing gets the same y value, namely 1.119 and the same tolerance value, namely 0.894 . it means that the model of regression used is good because there is no multicollinearity.

\section{Autocorrelation Test}

A model of regression where has a correlation between one variable and another on different observations of time or individually, the model experiences autocorrelation because when variables are correlated, there will be disturbances in it. Autocorrelation can be known from value of Durbin-Watson. If the DW value is between -2 to 2 then autocorrelation is not occurred to the model.

In Table 5, got result of the value of Durbin-Watson obtained is 2.075 where value obtained is not between -2 and 2 values, it means the model of regression used is confounding or autocorrelation.

\section{Hypothesis testing}

\section{Coefficient Determination $\left(\mathbf{R}^{2}\right)$}

Coefficient determination $\left(\mathrm{R}^{2}\right)$ can be seen from the table summary ${ }^{\mathrm{b}}$ model on the $\mathrm{R}$ square. In table 5 , got the $\mathrm{R}$ square result is 0.089 , it means the independent variable of mudarabah financing and 
Islamiyati, et al/Jurnal Ekonomi Syariah Teori dan Terapan Vol. 8 No. 3 Mei 2021: 255-263

musharakah financing effects the variable return on equity $(\mathrm{ROE})$ by $8.9 \%$, while other factors have a huger influence of $91.1 \%$ in effecting return on equity (ROE).

\section{The $t$ statistical test (partial test)}

In table 6 , it can be seen that the $t$ test results on mudarabah financing obtained value of t-count is 1.173, significance value is 0.247 and it can be seen that a t table of 2.017 while musharakah financing obtained t-calculated value of 1.196, a significance value of 0.246 and a t table of 2.017. If the value of significance obtained is less than 0.05 and t-calculated value obtained is greater than the table, then $\mathrm{H}_{0}$ is refused and $\mathrm{H}_{\mathrm{a}}$ is admitted and if significance value obtained gets a result of more than 0.05 and the value of $\mathrm{t}$-calculated obtained is lesser rather than $\mathrm{t}$ table, $\mathrm{H}_{0}$ is admitted and $\mathrm{H}_{\mathrm{a}}$ is refused.

Significance results of mudarabah financing obtained from the calculation of 0.247 where this value is huger than 0.05 and $t$ value of 1.173 is lesser than $t$ table 2.017, so $\mathrm{H}_{0}$ is admitted and $\mathrm{Ha}$ is refused, so it can be concluded that mudarabah financing has no effect on return on equity (ROE). Significance results of musharakah financing obtained from the calculation of 0.246 where this value is huger than 0.05 and the $t$ value of 1.176 is lesser than the $t$ table 2.017, so $\mathrm{H}_{0}$ is admitted and $\mathrm{H}_{\mathrm{a}}$ is refused, so it can be concluded that musharakah financing has no effect on return on equity (ROE).

\section{The F statistical test (simultaneous)}

In Table 7, it can be seen that the F count obtained is 2.045 , the significance value is 0.142 and the $\mathrm{F}$ table is 3.22. To find out the mutual relationship between mudarabah and musharakah financing on return on equity (ROE), to reveal that if $\mathrm{F}$ count is huger than $\mathrm{F}$ table then $\mathrm{H}_{0}$ is refused and $\mathrm{H}_{\mathrm{a}}$ is admitted and if the calculated $\mathrm{F}$ value is lesser than $\mathrm{F}$ table then $\mathrm{H}_{0}$ is admitted and $\mathrm{H}_{\mathrm{a}}$ is refused.

From the results of the calculation, it can be seen that the calculated $\mathrm{f}$ value obtained is 2.045 lesser than 3.22 and the significance value is huger than 0.05 , so $\mathrm{H}_{0}$ is admitted and $\mathrm{H}_{\mathrm{a}}$ is refused, which means that together mudarabah financing and musharakah financing have no effect on return on equity (ROE).

\section{The effect of mudarabah financing on return on equity (ROE)}

The increase or decrease in mudarabah financing does not affect banks in increasing return on equity (ROE) this is because mudarabah financing results in uncertainty in obtaining bank profits. The profits obtained by the bank are adjusted to the business profits generated by the customer so that the profits that the bank gets are uncertain (Putra \& Hasanah, 2016).

\section{The effect of musharakah financing on return on equity (ROE)}

Musharaka financing distributed by Islamic banking has increased every year and the risk of financing received has increased every year which causes musharaka financing to have no significant effect on changes in return on equity (ROE) (A. E. Rianti, 2019).

\section{CONCLUSION}

From the results of calculations and analysis conducted by researchers, the following conclusions can be drawn:

1. Mudarabah financing does not significantly affect return on equity (ROE)

2. Musharakah financing does not significantly affect return on equity (ROE)

3. Together, mudarabah financing and musharakah financing do not significantly affect return on equity (ROE)

4. Mudarabah financing and musharakah financing only effect the return on equity (ROE) of $8.9 \%$ and the rest is affected by other factors.

Mudarabah financing does not affect return on equity because collection and allocation of fund on mudarabah financing in generating profit for return on equity allocated to finance is not the main source. Same with mudarabah, musharakah financing also does not affect return on equity because not only 
Islamiyati, et al/Jurnal Ekonomi Syariah Teori dan Terapan Vol. 8 No. 3 Mei 2021: 255-263

financing is able to make value of musharakah financing increase the return on equity but profit sharing also affect because the aims of musharakah financing are to finance an investment.

In this research, there are still many limitations found, namely the sample used is still limited to Islamic commercial banks, it does not extend to other Islamic sectors and also the period used is only 5 years from 2015-2019. Future studies can use a wider sample, longer periods also use more variables in influencing return on equity (ROE).

\section{BIBLOGRAPHY}

Daulay, P. I. S. (2019). Pengaruh pendapatan bagi hasil pembiayaan mudharabah dan pembiayaan musyarakah terhadap return on equity (ROE) Pada PT. Bank Syariah Mandiri, Tbk. Skripsi tidak dipublikasikan. Medan: Universitas Islam Negeri Sumatera Utara.

Fatmawati, R. (2016). Analisis pengaruh pembiayaan mudharabah, musyarakah dan murabahah terhadap kemampu labaan BPR Syariah Artha Surya Barokah Semarang. Skripsi tidak dipublikasikan. Semarang: Universitas Muhammadiyah Semarang.

Maharani, S. (2019). Pengaruh pembiayaan mudharabah dan pembiayaan musyarakah terhadap return on equity (ROE) pada bank umum syariah periode 2013-2017. Skripsi tidak dipublikasikan. Ponorogo: Institut Agama Islam Negeri Ponorogo.

Mahmudin. (2018). Pengaruh pembiayaan mudharabah terhadap tingkat return on equity (ROE) pada bank syariah yang terdaftar di Bank Indonesia. The Asia Pacific Journal of Management, 05(03), 153162.

Nalta, S., Wijaya, I., \& Al Amin, H. (2018). Pengaruh pembiayaan mudharabah dan musyarakah terhadap return on equity pada PT. Bank Pembiayaan Rakyat Syariah di Indonesia. El-Amwal, 1(2), 23-33.

Nataliawati, R. (2018). Pengaruh rasio produk pembiayaan syariah terhadap return on equity bank umum syariah di Indonesia. Tesis tidak dipublikasikan. Surabaya: Universitas Wijaya Kusuma Surabaya.

Ningrum, M. H., Setiono, H., \& Dwihandoko, T. H. (2019). Analisis pengaruh pendapatan murabahah, musyarakah, dan ijarah terhadap profitabilitas bank syariah (Studi empiris pada bank syariah periode 2015 - 2018). Skripsi tidak dipublikasikan. Mojokerto: Universitas Islam Majapahit.

Putra, P., \& Hasanah, M. (2016). Pengaruh pembiayaan mudharabah, musyarakah, murabahah, dan ijarah terhadap profitabilitas 4 bank umum syariah periode 2013-2016. Jurnal Organisasi Dan Manajemen, 14(2), 140-150. https://doi.org/10.33830/jom.v14i2.159.2018

Rahayu, Y. S., Husaini, A., \& Azizah, D. F. (2016). Pengaruh pembiayaan bagi hasil mudharabah dan musyarakah terhadap profitabilitas (Studi pada bank umum syariah yang terdaftar pada bursa efek Indonesia periode 2011-2014 ). Jurnal Administrasi Bisnis (JAB), 33(1), 61-68.

Rianti, A. E. (2019). Analisis pengaruh pembiayaan mudharabah, musyarakah, murabahah dan ijarah terhadap tingkat profitabilitas return on equity (ROE) pada PT. Bank Syariah Mandiri periode 2011-2018. Skripsi tidak dipublikasikan. Surakarta: Universitas Muhammadiyah Surakarta.

Rianti, F. A., \& Elmanizar. (2019). Pengaruh piutang murabahah, pembiayaan mudharabah dan pembiayaan musyarakah terhadap profitabilitas bank syariah. Jurnal Pajak, Akuntansi, Sistem Informasi, dan Auditing, 1(1), 58-82.

Sari, D. W., \& Anshori, M. Y. (2016). Pengaruh pembiayaan murabahah, istishna, mudharabah, dan musyarakah terhadap profitabilitas (studi pada bank syariah di Indonesia periode Maret 2015 Agustus 2016). Accounting and Management Journal, 1(1), 1-8. https://doi.org/10.33086/amj.v1i1.68

Wibowo, A., \& Sunarto. (2014). Pengaruh pembiayaan mudharabah dan musyarakah terhadap profitabilitas perbankan syariah (studi kasus pada bank pembiayaan rakyat syariah Daerah Istimewa Yogyakarta yang terdaftar di Bank Indonesia periode 2012-2014). Syariah Paper Accounting FEB UMS, 115124. 
Islamiyati, et al/Jurnal Ekonomi Syariah Teori dan Terapan Vol. 8 No. 3 Mei 2021: 255-263

\section{ATTACHMENT}

Table 2.

Descriptive Statistics

\begin{tabular}{llrrrr}
\hline & N & \multicolumn{1}{c}{ Minimum } & \multicolumn{1}{c}{ Maximum } & \multicolumn{1}{c}{ Mean } & \multicolumn{1}{c}{ Std. Deviation } \\
\hline Mudarabah & 45 & 4513711303 & 8701140000000 & 934692890357,80 & 1466452478291,45 \\
\hline Musharakah & 45 & 638463460000 & 25956876000000 & 6500762150075,55 & 6784048029017,38 \\
\hline ROE & 45 & $-94,01$ & 15,66 & $-1,64$ & 19,47 \\
\hline Valid N & 45 & & & &
\end{tabular}

Source: Output SPSS 25.2021

Table 3.

Normality Test

One-Sample Kolmogorov-Smirnov Test

\begin{tabular}{|c|c|c|}
\hline \multicolumn{3}{|c|}{ One-Sample Kolmogorov-Smirnov Test } \\
\hline & & Unstandardized Residual \\
\hline $\mathrm{N}$ & & 45 \\
\hline \multirow{2}{*}{ Normal Parameters ${ }^{\mathrm{a}, \mathrm{b}}$} & Mean &, 0000000 \\
\hline & Std. Deviation & 18,58932661 \\
\hline \multirow[t]{3}{*}{ Most Extreme Differences } & Absolute & ,267 \\
\hline & Positive & ,213 \\
\hline & Negative &,- 267 \\
\hline Test Statistic & & ,267 \\
\hline Asymp. Sig. (2-tailed) & & $1,1758 \mathrm{E}-8$ \\
\hline \multicolumn{3}{|l|}{ a. Test distribution is Normal. } \\
\hline \multicolumn{3}{|l|}{ b. Calculated from data. } \\
\hline c. Lilliefors Significance Correction. & & \\
\hline
\end{tabular}

Source: Output SPSS 25.2021

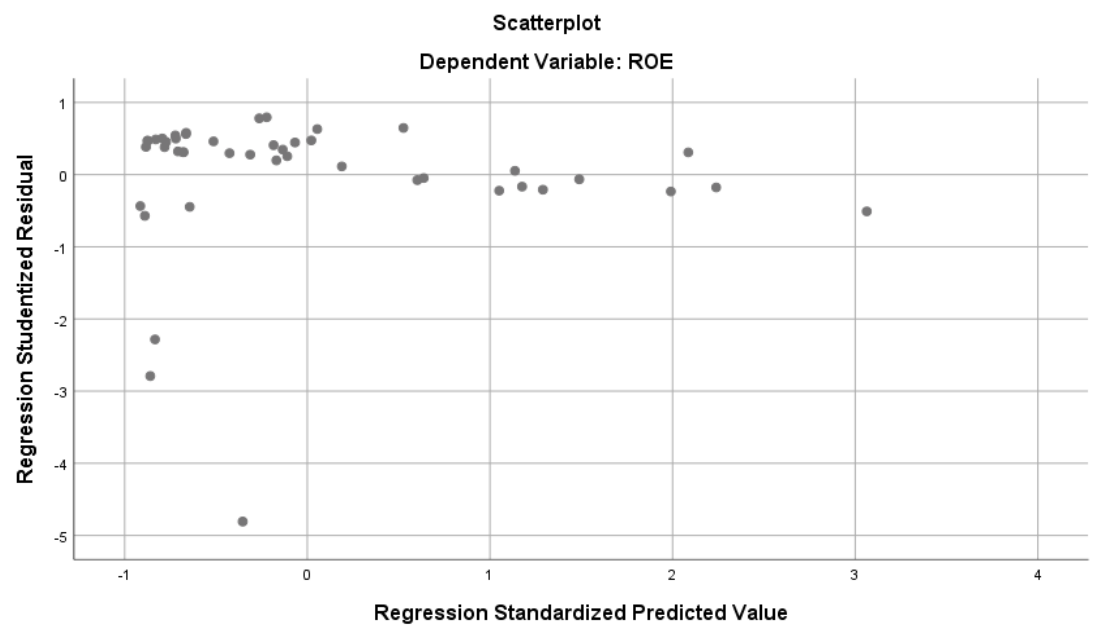

Source: Output SPSS 25.2021

Figure 1.

Heteroxidity Test 
Islamiyati, et al/Jurnal Ekonomi Syariah Teori dan Terapan Vol. 8 No. 3 Mei 2021: 255-263

Table 4.

Multicollinearity Test

\begin{tabular}{|c|c|c|c|}
\hline \multicolumn{4}{|c|}{ Coefficients $^{\mathrm{a}}$} \\
\hline \multirow{2}{*}{\multicolumn{2}{|c|}{ Model }} & \multicolumn{2}{|c|}{ Collinearity Statistics } \\
\hline & & Tolerance & VIF \\
\hline 1 & Mudarabah &, 894 & 1,119 \\
\hline & Musharakah & ,894 & 1,119 \\
\hline
\end{tabular}

a. Dependent Variable: ROE

Source: Output SPSS 25.2021

Table 5.

Autocorrelation Test and Coefficient Determinant $\left(\mathrm{R}^{2}\right)$

\begin{tabular}{|c|c|c|c|c|c|}
\hline \multicolumn{6}{|c|}{ Model Summary ${ }^{\mathrm{b}}$} \\
\hline Model & $\mathrm{R}$ & R Square & $\begin{array}{l}\text { Adjusted R } \\
\text { Square }\end{array}$ & $\begin{array}{l}\text { Std. Error of the } \\
\text { Estimate }\end{array}$ & $\begin{array}{l}\text { Durbin- } \\
\text { Watson }\end{array}$ \\
\hline 1 &, $298^{\mathrm{a}}$ & ,089 &, 045 & 19,02678239 & 2,075 \\
\hline \multicolumn{6}{|c|}{ a. Predictors: (Constant), Musharakah, Mudarabah } \\
\hline b. Depe & e: ROE & & & & \\
\hline
\end{tabular}

Table 6.

t Statistical Test (partial test)

\begin{tabular}{|c|c|c|c|c|c|c|}
\hline \multicolumn{7}{|c|}{ Coefficients $^{\mathrm{a}}$} \\
\hline \multirow{2}{*}{\multicolumn{2}{|c|}{ Model }} & \multicolumn{2}{|c|}{$\begin{array}{l}\text { Unstandardized } \\
\text { Coefficients }\end{array}$} & \multirow{2}{*}{$\begin{array}{c}\begin{array}{c}\text { Standardized } \\
\text { Coefficients }\end{array} \\
\text { Beta }\end{array}$} & \multirow[t]{2}{*}{$\mathrm{t}$} & \multirow[t]{2}{*}{ Sig. } \\
\hline & & B & Std. Error & & & \\
\hline \multirow[t]{3}{*}{1} & (Constant) & $-7,331$ & 4,071 & & $-1,801$ & 079 \\
\hline & Mudarabah & 2,427 &, 000 &, 183 & 1,173 & ,247 \\
\hline & Musharakah & 5,257 &, 000 &, 183 & 1,176 & ,246 \\
\hline
\end{tabular}

a. Dependent Variable: ROE

Source: Output SPSS 25.2021

Table 7.

F Statistical Test (Simultanous)

\begin{tabular}{|c|c|c|c|c|c|c|}
\hline \multicolumn{7}{|c|}{ ANOVA $^{\mathrm{a}}$} \\
\hline \multicolumn{2}{|c|}{ Model } & Sum of Squares & $\mathrm{df}$ & $\begin{array}{c}\text { Mean } \\
\text { Square }\end{array}$ & $\mathrm{F}$ & Sig. \\
\hline \multirow[t]{3}{*}{1} & Regression & 1480,969 & 2 & 740,484 & 2,045 &, $142^{\mathrm{b}}$ \\
\hline & Residual & 15204,775 & 42 & 362,018 & & \\
\hline & Total & 16685,743 & 44 & & & \\
\hline \multicolumn{7}{|c|}{ a. Dependent Variable: ROE } \\
\hline \multicolumn{7}{|c|}{ b. Predictors: (Constant), Musharakah, Mudarabah } \\
\hline
\end{tabular}

Source: Output SPSS 25.2021 